\title{
Bycatch composition of cutlassfish trawlers during fishing season in Bushehr and Hormozgan, Persian Gulf, Iran
}

\author{
AHMAD FOULADI SABET ${ }^{1}$, SEYED YOUSEF PAIGHAMBARI ${ }^{1, \bullet}$, MOJTABA POULADI $^{1}$, \\ HADI RAEISI ${ }^{2}$, REZA ABBASPOUR NADERI ${ }^{3}$ \\ ${ }^{1}$ Department of Fisheries, Faculty of Fisheries and Environmental Sciences, Gorgan University of Agricultural Sciences and Natural Resources, Gorgan, \\ Golestan, Iran, Tel: +98-9122069187, ’email: sypaighambari@gau.ac.ir \\ ${ }^{2}$ Department of Fisheries, Faculty of Agriculture and Natural Resources, Gonbad Kavous University, Gonbad Kavous, Golestan, Iran \\ ${ }^{3}$ Department of Capture Fisheries, Iranian Fisheries Research Organization, Tehran, Iran
}

Manuscript received: 20 October 2018. Revision accepted: 13 November 2018.

\begin{abstract}
Fouladi Sabet A, Paighambari SY, Pouladi M, Raeisi H, Abbaspour Naderi R. 2018. Bycatch composition of cutlassfish trawlers during fishing season in Bushehr and Hormozgan, Persian Gulf, Iran. Biodiversitas 19: 2275-2282. This investigation was conducted to determine the bycatch composition of cutlassfish (Trichiurus lepturus) trawlers in Bushehr and Hormozgan waters during fishing season 2013. Data collection was carried out in the summer for Bushehr and in the autumn for Hormozgan province for one month. All trawler vessels were equipped with a $36 \mathrm{~m}$ head rope and $75 \mathrm{~mm}$ stretched mesh size in the codend and 90 to $200 \mathrm{~mm}$ stretched mesh size in the panel. 47 species included 35 species of teleosts, 9 species of elasmobranches and 3 species of invertebrates were identified in Bushehr. Also, 48 species included 38 species of teleosts, 7 species of elasmobranches and 3 species of invertebrates were identified in Hormozgan. The weight and numerical averages of bycatch species were $25.41\left(\mathrm{~kg} \mathrm{~h}^{-1}\right)$ and $205.9\left(\mathrm{n} \mathrm{h}^{-1}\right) \mathrm{in} \mathrm{Bushehr}$, and $92.58\left(\mathrm{~kg} \mathrm{~h}^{-1}\right)$ and $440.4\left(\mathrm{n} \mathrm{h}^{-1}\right)$ in Hormozagan. I. megaloptera, S. tumbil, N. japonicus, D. acuta, C. sexfasciatus, L. equulus in Bushehr and P. sextarius, I. megalopteran, M. cinereus, P. macrophthalmus, N. japonicus and $S$. tumbil in Hormozgan had highest catch weight. Based on the weight and number, PCA and nMDS methods were indicative of two different assemblages in hunting places. Furthermore, ANOSIM similarity analysis confirmed the results of PCA and nMDS and showed a significant difference in the catch composition of two fishing zones.
\end{abstract}

Keywords: Bycatch, cutlassfish, trawl, Bushehr, Hormozgan, Persian Gulf

\section{INTRODUCTION}

The Persian Gulf is a semi-enclosed body of water, located in the Middle East. It is bounded by the Shatt alArab river delta in the northwest and by the Strait of Hormuz in the southeast. This gulf is bordered by Iran, Iraq, Bahrain, Qatar, Kuwait, Saudi Arabia, and the United Arab Emirates (UAE). The Gulf supports highly productive coastal habitats, including intertidal mudflats, seagrass, algal beds, mangroves, and coral reefs (Price 1993; Sheppard et al. 2010; Sale et al. 2011). However this Gulf encompasses numerous endemic species and a diversity of dynamic habitats, it has less biological diversity than the adjacent Indian Ocean due to severe ecological situations (Khan and Munawar 2002; Sale et al. 2011). According to the reports of the United Nations Food and Agriculture Organization (FAO), the fishery potential in the Persian Gulf is estimated to be 550000 tons or eight times more than the Gulf of Oman. A large number of aquatic species in the Persian Gulf and Oman Sea have made these two ecosystems unique in the world (Kardovani 1995; Sale et al. 2011).

The amount of bycatch depends on the used fishing gears and various fishing methods (Rochet et al. 2002; Eayrs 2007; Raeisi et al. 2012). Nowadays, bycatch production is one of the serious threats to fish stocks by commercial fishing and includes about $40.4 \%$ of the total marine catch which is poured into the sea as discard fish (Kennelly 1995; Pauly et al. 2002; Worm et al. 2006; Kumar and Deepthi 2006; Davies et al. 2009; Queirolo et al. 2011). Huge amounts of bycatch are produced by trawl nets in the fishing operations (Harrington et al. 2006). According to FAO (2007), the amount of global bycatch production was estimated between 17.9 and 395.5 million tons (an average of 27 million tons). Shrimp fishing by trawl is the main reason for creating the bycatch problem in the tropical world which included $27 \%$ of global discard fish (FAO 2007). The selectivity of fishing gear is usually weak and is largely dependent on target species, particularly in the fishing by the bottom trawler which is considered as an active fishing gear (Andrew et al. 1995; Harrington et al. 2006). Currently, the issue of bycatch and the destruction of marine ecosystems has become one of the most important problems that could have a very serious impact on food security of more than 1 billion people which fish are the main source of protein for them (Harrington et al. 2006). Trawl nets are standard tools for surveying aquatic resources, but at the same time, they non-selectively catch fish stocks in marine environments. Thus, potentially, they may provide misleading information about the fish population (Charles et al. 2011; Raeisi et al. 2011). Trawl net has a lot of discard fish in the content of fishing operation (Alverson et al. 1994). This fishing gear 
has a very low selectivity in catching fish and catches different kinds of commercial and non-commercial species (Clucas 1997; Eayrs 2007). Bycatch reduction devices can significantly decrease obtained bycatch and discard fish in the trawls (Walmsley et al. 2007; Bellido et al. 2011; Charles et al. 2011; Raeisi et al. 2011). So far, several studies have been conducted on bycatch compositions in the Persian Gulf (El Sayed 1996; Valinassab et al. 2006; Paighambari and Daliri 2012; Hosseini et al. 2012; Raeisi et al. 2012; Eighani and Paighambari 2013; Paighambari and Eighani 2016). The main purpose of this study was determining the bycatch composition of cutlassfish trawlers during the fishing season of cutlassfish (Trichiurus lepturus) in Bushehr and Hormozgan waters. The Results of this study can provide basic information for sustainable fisheries management in the Persian Gulf.

\section{MATERIALS AND METHODS}

\section{Data collection}

During this project, fishing operations were carried out in the two fishing grounds of Bushehr and Hormozgan provinces located in the Persian Gulf. Data collection was carried out in the summer for Bushehr province and in the autumn for Hormozgan province for one month. All trawler vessels were equipped with a $36 \mathrm{~m}$ head rope and $75 \mathrm{~mm}$ stretched mesh size in the codend and 90 to $200 \mathrm{~mm}$ stretched mesh size in the panel.

Thirty-six hauling operations were conducted in the waters of Bushehr province in the summer. The duration of each hauling period was between 1.83 and 5.5 hours with an average of 3.71 hours in this region. The average speed of hauling was $3.5 \mathrm{mph}$. In terms of position, the geographical points of operation were located in the Motaf fishing grounds (latitude $=27^{\circ} 04^{\prime}$ to $27^{\circ} 53^{\prime} \mathrm{N}$; longitude $=$ $51^{\circ} 03^{\prime}$ to $51^{\circ} 47^{\prime} \mathrm{E}$ ) and the hauling area was 71.1038 square miles. In addition, 37 hauling operations were done in the Hormozgan province in the autumn. The duration of each hauling period was between 1.16 and 4.16 hours with an average of 3.06 in this region. The average speed of hauling was $2.84 \mathrm{mph}$. In terms of position, the geographical points of operation were located between Hengam Island and Greater Tunb (latitude $=26^{\circ} 18^{\prime}$ to $26^{\circ}$ $22^{\prime} \mathrm{N}$; longitude $=55^{\circ} 17^{\prime}$ to $55^{\circ} 50^{\prime} \mathrm{E}$ ( and the hauling area was 485.058 square miles (Fig. 1). The operations were mainly carried out at depths between 40 to 75 meter in the fishing grounds of Bushehr and Hormozgan provinces. All fishes were counted, weighed and identified to the species according to Fisher and Binachi (1984) and Rivaton et al. (1990).

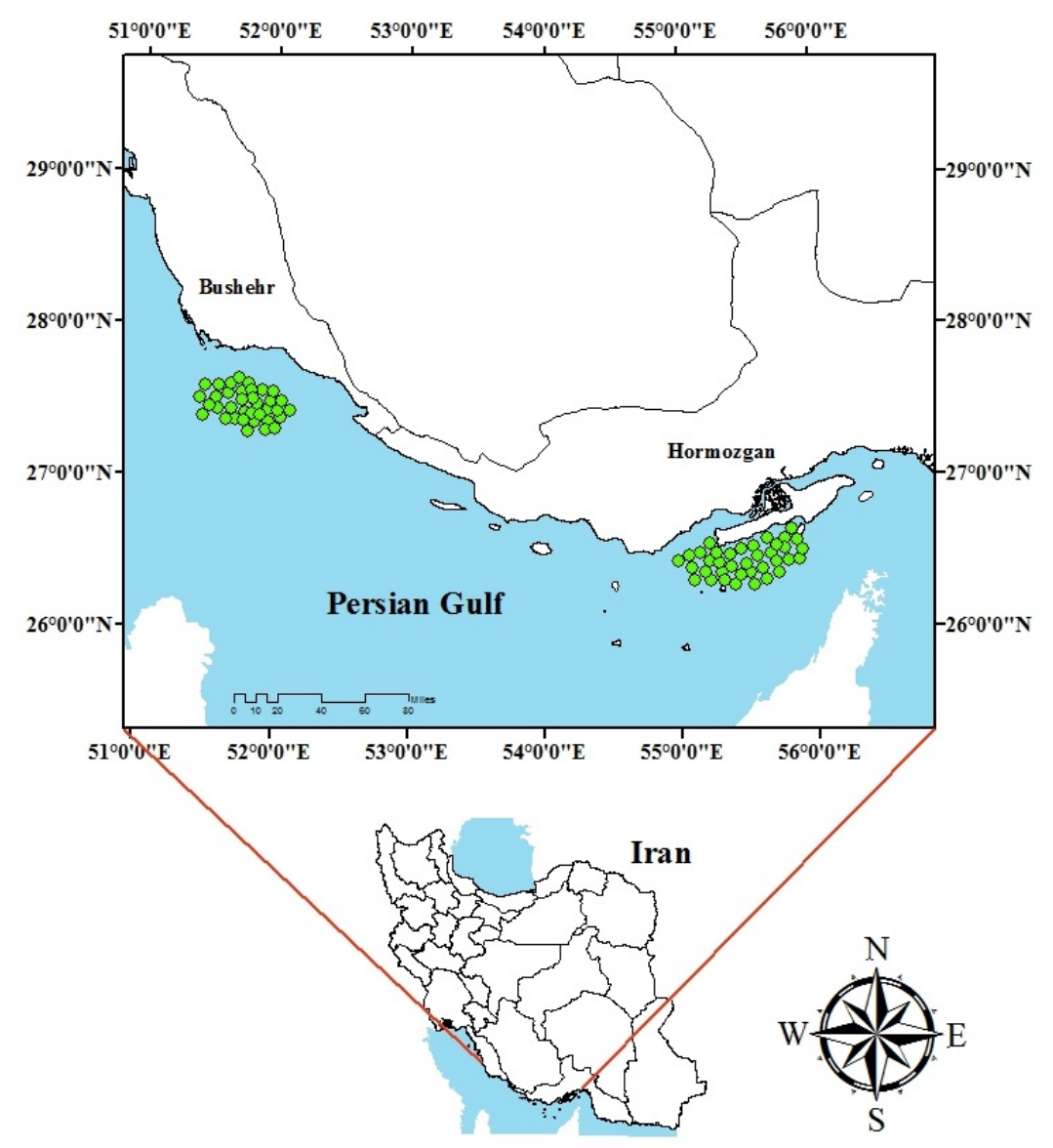

Figure 1. Location of study areas in the waters of the Persian Gulf, Iran 


\section{Statistical analysis}

Non-metric multidimensional scaling (nMDS) was used to examine similarities of bycatch composition between Bushehr and Hormozgan fishing grounds. Data were fourth-root transformed to reduce the influence of highly abundant taxa. The degree of similarity between samples was graphically depicted in the form of an ordination plot, which is a multidimensional relationship between all samples. Ordinations with stress values less than 0.2 are useful for interpreting relationships among samples. Because the stress values in some ordinations were near 0.2 , analysis of similarities (ANOSIM) was used to consider which fish communities in analyzed groups varied statistically. Similarity percentages (SIMPER) was used to determine which species were responsible for differences between defined groups by ANOSIM (Clarke 1993). All multivariate analyses were carried out using PRIMER software version 5.2.2.

\section{RESULTS AND DISCUSSION}

\section{Catch composition}

Identification of fish species is an important step towards understanding their biology and optimal management of sustainable exploitation of stocks. A comprehensive study of the species characteristics at the population level and its variability will provide a better understanding of the stock situations in the current conditions of aquatic ecosystems and the interaction between species and ecosystems (Kaymaram 2000).

According to the trawl fishing methods, bottom and midwater trawlers have a high diversity of species in their catch composition and selectively catch of all fish in their fishing operations (Alverson et al. 1994; Ilona et al. 2001; Kumar and Deepthi 2006). Lack of BRDs (Bycatch reduction devices) in cutlassfish trawls cause high amounts of total bycatch (Raeisi et al. 2011). During this research, the proportion of bycatch species to target species was 0.062 in the Motaf fishing grounds in Bushehr province. Among 47 caught species in this region, 35 species belonging to 25 families of teleosts, 9 species belonging to 6 families of elasmobranches and 3 species belonging to 3 families of invertebrates were identified (Table 1). The weight and numerical averages of bycatch species were $25.41\left(\mathrm{~kg} \mathrm{~h}^{-1}\right)$ and $205.9\left(\mathrm{n} \mathrm{h}^{-1}\right)$, respectively. The proportion of bycatch weight to target weight was 1 to 13 . In terms of number, the bycatch species and the target species had 17.96 and $82.04 \%$ of total catch, respectively. The weight percentages for discard species with commercial and non-commercial values and large discard species (often elasmobranches) were 50.63, 41.32 and $8.03 \%$ of total bycatch weight, respectively. The numerical percentages for these bycatch species were 14.78, 84.79 and $0.42 \%$, respectively. In addition, teleosts, elasmobranches, and invertebrates had 92.21, 6.564 and $1.226 \%$ of the total catch weight, respectively. In terms of number, teleosts, elasmobranches, and invertebrates were included $99.74,0.057$, and $0.203 \%$ of the total catch, respectively (Figure 2; Table 1).
Among the caught bycatch species using trawls, the highest weight $\left(6.25 \pm 2.47 \mathrm{~kg} \mathrm{~h}^{-1}\right)$ and numerical $(65.2 \pm$ $26.2 \mathrm{n} \mathrm{h}^{-1}$ ) averages belonged to Illisha megaloptera. Aetomylaeus maculatus with $1.32 \%$ of total bycatch weight and $20.19 \%$ of the caught elasmobranches weight had the highest weight average of the elasmobranches. Himantura walga with $0.1 \%$ of the total bycatch number and $34.09 \%$ of the caught elasmobranches number had the highest numerical average of the elasmobranches. In Hormozgan, the proportion of bycatch species to target species was 0.326 in Hengam Island and Greater Tunb. Among 48 species, 38 species belonging to 28 families of teleosts, 7 species belonging to 7 families of elasmobranches and 3 species belonging to 3 families of invertebrates were identified (Table 2). The weight and numerical averages of bycatch species were $92.58\left(\mathrm{~kg} \mathrm{~h}^{-1}\right)$ and $440.4\left(\mathrm{n} \mathrm{h}^{-1}\right)$, respectively. The proportion of bycatch weight to target weight was 1 to 2.28. In terms of number, the bycatch species and the target species had 37.04 and $62.96 \%$ of total catch, respectively (Fig. 1). The weight percentages for discard species with commercial and non-commercial values and large discard species (often elasmobranches) were $61.24,22.55$ and 16.21 of total bycatch weight, respectively. The numerical percentages for these bycatch species were $60.13,37.32$ and $2.55 \%$, respectively. In addition, teleosts, elasmobranches, and invertebrates had $90.057,9.708$ and $0.235 \%$ of the total catch weight, respectively. In terms of number, teleosts, elasmobranches, and invertebrates were included $98.466,1.17$, and $0.364 \%$ of the total catch, respectively (Figure 3; Table 2).

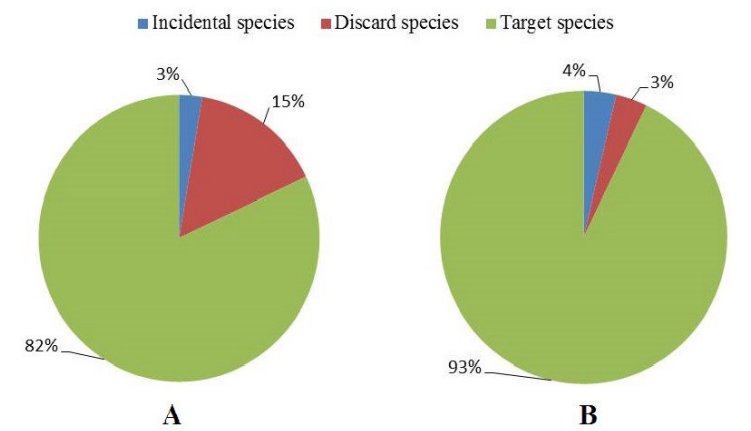

Figure 2. Weight (A) and numerical (B) ratio of incidental, discard and target species to total catch in Bushehr province

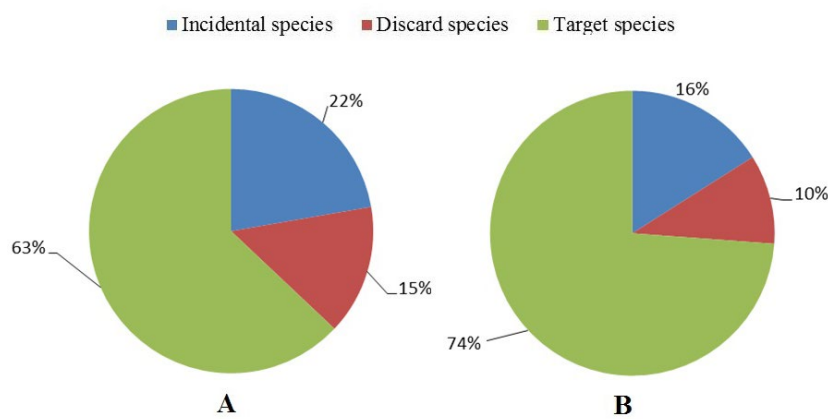

Figure 3. Weight (A) and numerical (B) ratio of incidental, discard and target species to total catch in Hormozgan province 
Table 1. Bycatch composition of trawlers during sampling month in Bushehr Province, Iran

\begin{tabular}{|c|c|c|c|c|c|}
\hline Fish species & $\begin{array}{l}\begin{array}{l}\text { Occurrence } \\
\text { percent } \%\end{array} \\
\end{array}$ & $\begin{array}{c}\text { Average weight } \\
\left(\mathrm{kgh}^{-1}\right) \pm \mathrm{SE}\end{array}$ & $\begin{array}{c}\text { Average number } \\
\left(\mathrm{nh}^{-1}\right) \pm \mathrm{SE}\end{array}$ & $\begin{array}{c}\text { Weight } \\
\text { percent \% }\end{array}$ & $\begin{array}{c}\text { Number } \\
\text { percent \% }\end{array}$ \\
\hline Ilisha megaloptera & 100 & $2.47 \pm 6.25$ & $26.2 \pm 65.2$ & 26.48 & 34.37 \\
\hline Argyrops spinifer & 38.88 & $0.14 \pm 0.33$ & $0.13 \pm 0.31$ & 1.11 & 0.116 \\
\hline Lieognathus equulus & 86.11 & $0.27 \pm 0.74$ & $12.44 \pm 28.35$ & 2.776 & 12.268 \\
\hline Secutor insidiator & 5.55 & $0.033 \pm 0.034$ & $0.25 \pm 0.259$ & 0.133 & 0.123 \\
\hline Acanthopagrus latus & 2.77 & $0.0058 \pm 0.0058$ & $0.009 \pm 0.009$ & 0.018 & 0.003 \\
\hline Carangoides malabaricus & 27.77 & $0.06 \pm 0.1$ & $2.47 \pm 6.25$ & 0.45 & 0.199 \\
\hline Nemipterus japonicus & 91.66 & $0.98 \pm 3.79$ & $6 \pm 19.98$ & 12.695 & 8.057 \\
\hline Upeneus sulphureus & 66.66 & $0.02 \pm 0.09$ & $0.92 \pm 2.98$ & 0.315 & 1.218 \\
\hline Saurida tumbil & 100 & $0.81 \pm 5.47$ & $1.17 \pm 8.31$ & 20.495 & 3.832 \\
\hline Sphyreana putnamiae & 33.88 & $0.26 \pm 0.55$ & $2.55 \pm 3.67$ & 2.34 & 2.01 \\
\hline Alectis indicus & 38.88 & $0.18 \pm 0.63$ & $0.07 \pm 0.25$ & 2.408 & 0.119 \\
\hline Dussumieria acuta & 16.66 & $2.5 \pm 2.52$ & $80.86 \pm 81.3$ & 8.465 & 33.646 \\
\hline Scomberomorus commerson & 2.77 & $0.085 \pm 0.085$ & $0.0087 \pm 0.0087$ & 0.285 & 0.003 \\
\hline Pterois russellii & 2.77 & $0.0034 \pm 0.0034$ & $0.009 \pm 0.009$ & 0.01 & 0.003 \\
\hline Caranx sexfasciatus & 44.44 & $1.55 \pm 1.57$ & $0.14 \pm 0.43$ & 5.996 & 0.21 \\
\hline Carangoides chrysophrys & 35.55 & $0.05 \pm 0.15$ & $0.05 \pm 0.15$ & 2.352 & 0.072 \\
\hline Rachycentron canadum & 2.77 & $0.007 \pm 0.007$ & $0.01 \pm 0.01$ & 0.039 & 0.003 \\
\hline Lagocephalus inermis & 27.77 & $0.2 \pm 0.09$ & $0.12 \pm 0.04$ & 0.86 & 0.065 \\
\hline Netuma thalassina & 5.55 & $0.041 \pm 0.035$ & $0.016 \pm 0.011$ & 0.148 & 0.007 \\
\hline Cyclichthys orbicularis & 2.77 & $0.0018 \pm 0.0018$ & $0.009 \pm 0.009$ & 0.005 & 0.003 \\
\hline Selaroides leptolepis & 61.11 & $0.28 \pm 0.08$ & $3.29 \pm 1.55$ & 1.132 & 1.679 \\
\hline Muraenesox cinereus & 16.66 & $0.12 \pm 0.06$ & $0.06 \pm 0.02$ & 0.451 & 0.029 \\
\hline Stephanolepis diaspros & 25 & $0.016 \pm 0.008$ & $0.097 \pm 0.031$ & 0.068 & 0.047 \\
\hline Megalaspis cordyla & 5.55 & $0.0039 \pm 0.0027$ & $0.014 \pm 0.01$ & 0.015 & 0.007 \\
\hline Pomadasys kaakan & 33.88 & $0.42 \pm 0.11$ & $0.14 \pm 0.04$ & 1.651 & 0.072 \\
\hline Grammoplites suppositus & 33.88 & $0.05 \pm 0.01$ & $0.25 \pm 0.06$ & 0.198 & 0.123 \\
\hline Epinephelus coioides & 19.44 & $0.17 \pm 0.09$ & $0.12 \pm 0.07$ & 0.542 & 0.039 \\
\hline Lutjanus erythropterus & 2.77 & $0.04 \pm 0.04$ & $0.02 \pm 0.02$ & 0.184 & 0.01 \\
\hline Fistularia petimba & 16.66 & $0.004 \pm 0.0019$ & $0.076 \pm 0.036$ & 0.014 & 0.029 \\
\hline Lepidotrigla bispinosa & 22.22 & $0.0087 \pm 0.0086$ & $0.18 \pm 0.07$ & 0.027 & 0.076 \\
\hline Parastromateus niger & 8.33 & $0.017 \pm 0.011$ & $0.029 \pm 0.018$ & 0.065 & 0.014 \\
\hline Psettodes erumei belcheri & 5.55 & $0.026 \pm 0.021$ & $0.014 \pm 0.01$ & 0.112 & 0.0007 \\
\hline Heniochus acuminatus & 2.77 & $0.001 \pm 0.001$ & $0.009 \pm 0.009$ & 0.005 & 0.003 \\
\hline Pseudosynanceia melanostigma & 8.33 & $0.038 \pm 0.024$ & $0.09 \pm 0.057$ & 0.125 & 0.036 \\
\hline Rhinobatos annandalei & 16.66 & $0.111 \pm 0.044$ & $0.07 \pm 0.02$ & 0.466 & 0.025 \\
\hline Sphyrna lewini & 2.77 & $0.009 \pm 0.009$ & $0.015 \pm 0.015$ & 0.035 & 0.007 \\
\hline Aetomylaeus maculatus & 2.77 & $0.55 \pm 0.55$ & $0.01 \pm 0.01$ & 1.325 & 0.003 \\
\hline Torpedo sinuspersici & 11.11 & $0.066 \pm 0.033$ & $0.057 \pm 0.028$ & 0.264 & 0.025 \\
\hline Carcharhinus sorrah & 13.88 & $0.03 \pm 0.01$ & $0.03 \pm 0.01$ & 1.096 & 0.0218 \\
\hline Carcharhinus dussumieri & 22.22 & $0.23 \pm 0.08$ & $0.07 \pm 0.02$ & 0.919 & 0.036 \\
\hline Himantura walga & 33.33 & $0.31 \pm 0.09$ & $0.11 \pm 0.03$ & 1.252 & 0.058 \\
\hline Dasyatis bennetti & 22.22 & $0.23 \pm 0.08$ & $0.07 \pm 0.02$ & 0.983 & 0.109 \\
\hline Aetomylaeus nichofii & 11.11 & $0.07 \pm 0.038$ & $0.052 \pm 0.027$ & 1.325 & 0.003 \\
\hline Sepia pharaonis & 69.44 & $0.34 \pm 0.07$ & $2.47 \pm 0.49$ & 1.228 & 1.119 \\
\hline Penaeus semisulcatus paucidentatus & 2.77 & $0.0002 \pm 0.0002$ & $0.009 \pm 0.009$ & 0.0008 & 0.003 \\
\hline Charybdis hoplites longicollis & 8.33 & $0.0019 \pm 0.0016$ & $0.071 \pm 0.057$ & 0.007 & 0.032 \\
\hline
\end{tabular}

Four species of teleosts including Polynemus sextarius, Nemipterus japonicus, Trichiurus lepturus, and Saurida tumbil were present in more than $90 \%$ of the trawl catch and they had the highest percentage of occurrence. Among the caught bycatch species using trawls, the highest weight average belonged to Polynemus sextarius $(26.63 \pm 11.26 \mathrm{~kg}$ $\mathrm{h}^{-1}$ ) and the highest numerical average belonged to Illisha megaloptera $\left(198.62 \pm 140.13 \mathrm{n} \mathrm{h}^{-1}\right)$. Himantura walga with $4.51 \%$ of total bycatch weight and $46.5 \%$ of the caught elasmobranches weight had the highest weight average of the elasmobranches fish. Also, Himantura walga with $0.79 \%$ of total bycatch number and $71.45 \%$ of the caught elasmobranches number had the highest numerical average of the elasmobranches.

Other studies conducted by trawl nets on the fish stocks have also indicated the high diversity of bycatch composition in the trawl harvesting activities in the Persian Gulf and the Gulf of Oman (Valinassab et al. 2006; Paighambari and Daliri 2012; Hosseini et al. 2012; Raeisi et al. 2013; Eighani and Paighambari 2013). The bycatch composition of cutlassfish trawls has a different catch composition in comparison with shrimp trawls in the Persian Gulf. Bycatches (discard and incidental) are considered to be an important quantity of catches for 
ecosystem-based fisheries management but generally informed data emphasis on landings (Pikitch et al. 2004). In this study, the weight ratio of caught cutlassfish was 12.87 times more than the weight of bycatch in Bushehr province which $92.79 \%$ belonged target species and $7.21 \%$ belonged to bycatch species. Also, the weight ratio of caught cutlassfish was 2.82 times more than the weight of bycatch in Hormozgan province which $72.82 \%$ belonged to the target species and $27.18 \%$ belonged to bycatch species. These results indicate that the amount of bycatch in
Hormozgan is higher than Bushehr which the results are consistent with the results of previous studies (Valinasab et al. 2006; Reaisi et al. 2012). The differences between the number of bycatches in two provinces can be due to differences in ecological and habitat conditions. The fishing grounds are close to various islands in Hormozgan and fish conditions for spawning and feeding are more suitable, then their accumulation in these areas is more than Bushehr.

Table 2. Bycatch composition of trawlers during sampling month in Hormozgan Province, Iran

\begin{tabular}{|c|c|c|c|c|c|}
\hline Fish species & $\begin{array}{l}\text { Occurrence } \\
\text { percent } \%\end{array}$ & $\begin{array}{c}\text { Average weight } \\
\left(\mathrm{kgh}^{-1}\right) \pm \mathrm{SE}\end{array}$ & $\begin{array}{c}\text { Average number } \\
\left(\mathbf{n h}^{-1}\right) \pm \mathrm{SE}\end{array}$ & $\begin{array}{c}\text { Weight } \\
\text { percent } \%\end{array}$ & $\begin{array}{c}\text { Number } \\
\text { percent } \%\end{array}$ \\
\hline Sphyreana putnamiae & 64.86 & $2.67 \pm 0.99$ & $8.58 \pm 6.49$ & 2.53 & 1.64 \\
\hline Otolithes ruber & 45.94 & $0.36 \pm 0.09$ & $0.43 \pm 0.1$ & 0.42 & 0.1 \\
\hline Pomadasys kaakan & 75.67 & $1.05 \pm 0.27$ & $1.26 \pm 0.34$ & 1.17 & 0.29 \\
\hline Drepane punctata & 45.94 & $0.49 \pm 0.13$ & $0.34 \pm 0.09$ & 0.54 & 0.08 \\
\hline Parastromateus niger & 48.64 & $0.63 \pm 0.21$ & $1.29 \pm 0.39$ & 0.78 & 0.33 \\
\hline Pampus argenteus & 37.83 & $1.31 \pm 0.55$ & $2.94 \pm 1.23$ & 1.64 & 0.77 \\
\hline Ilisha megaloptera & 72.97 & $17.91 \pm 12.61$ & $198.62 \pm 140.13$ & 15.5 & 36.11 \\
\hline Secutor insidiator & 24.32 & $0.09 \pm 0.03$ & $0.47 \pm 0.19$ & 0.09 & 0.1 \\
\hline Upeneus salphureus & 24.32 & $0.18 \pm 0.1$ & $3.81 \pm 2.1$ & 0.15 & 0.65 \\
\hline Muraenesox cinereus & 72.97 & $9.43 \pm 1.6$ & $4 \pm 0.66$ & 10.14 & 0.91 \\
\hline Nemipterus japonicus & 89.18 & $5.29 \pm 1.16$ & $22.52 \pm 4.84$ & 5.67 & 5.06 \\
\hline Polynemus sextarius & 100 & $25.63 \pm 11.26$ & $153.82 \pm 65.8$ & 23.42 & 29.42 \\
\hline Pennahia macrophthalmus & 56.75 & $9.3 \pm 2.47$ & $74.46 \pm 20.25$ & 9.62 & 16.05 \\
\hline Psettodes erumei & 13.51 & $0.11 \pm 0.06$ & $0.06 \pm 0.03$ & 0.09 & 0.01 \\
\hline Argyrops spinifer & 37.83 & $0.21 \pm 0.05$ & $0.22 \pm 0.05$ & 0.21 & 0.04 \\
\hline Selaroides leptolepis & 5.4 & $0.07 \pm 0.05$ & $0.08 \pm 0.05$ & 0.064 & 0.11 \\
\hline Saurida tumbil & 8.1 & $0.07 \pm 0.05$ & $0.04 \pm 0.02$ & 7.78 & 2.94 \\
\hline Scombermorus guttatus & 56.75 & $0.56 \pm 0.12$ & $0.76 \pm 0.17$ & 0.54 & 0.15 \\
\hline Mene maculate & 5.4 & $0.02 \pm 0.02$ & $0.18 \pm 0.18$ & 0.02 & 0.03 \\
\hline Grammoplites suppositus & 5.4 & $0.002 \pm 0.002$ & $0.01 \pm 0.01$ & 0.003 & 0.004 \\
\hline Eleutheronema tetradactylum & 5.4 & $0.07 \pm 0.05$ & $0.08 \pm 0.05$ & 0.05 & 0.01 \\
\hline Rachycentron canadum & 8.1 & $0.07 \pm 0.05$ & $0.04 \pm 0.02$ & 0.09 & 0.01 \\
\hline Scomberomorus commerson & 2.7 & $0.06 \pm 0.06$ & $0.009 \pm 0.009$ & 0.07 & 0.002 \\
\hline Epinephelus coioides & 13.51 & $0.22 \pm 0.11$ & $0.04 \pm 0.02$ & 0.28 & 0.01 \\
\hline Acanthopagrus latus & 35.13 & $0.11 \pm 0.03$ & $0.19 \pm 0.05$ & 0.13 & 0.04 \\
\hline Lagocephalus inermis & 8.1 & $0.04 \pm 0.02$ & $0.02 \pm 0.01$ & 0.05 & 0.008 \\
\hline Caranx sexfasciatus & 62.16 & $0.97 \pm 0.19$ & $3.02 \pm 0.56$ & 1.93 & 0.22 \\
\hline Carangoides chrysophrys & 8.1 & $0.09 \pm 0.05$ & $0.03 \pm 0.02$ & 0.098 & 0.008 \\
\hline Terapon jurbua & 2.7 & $0.002 \pm 0.002$ & $0.01 \pm 0.01$ & 0.002 & 0.002 \\
\hline Netuma thalassina & 43.24 & $2.93 \pm 1.09$ & $2.41 \pm 0.83$ & 2.63 & 0.45 \\
\hline Megalaspis cordyla & 24.32 & $0.13 \pm 0.05$ & $0.26 \pm 0.09$ & 0.16 & 0.04 \\
\hline Lutjanus erythropterus & 5.4 & $0.04 \pm 0.03$ & $0.01 \pm 0.01$ & 0.05 & 0.004 \\
\hline Siganus javus & 2.7 & $0.003 \pm 0.003$ & $0.006 \pm 0.006$ & 0.004 & 0.002 \\
\hline Himantura walga & 72.97 & $4.98 \pm 1.14$ & $4.06 \pm 0.94$ & 4.51 & 0.79 \\
\hline Aetobatus narinari & 2.7 & $0.4 \pm 0.4$ & $0.01 \pm 0.01$ & 0.38 & 0.002 \\
\hline Torpedo sinuspersici & 27.02 & $0.5 \pm 0.16$ & $0.27 \pm 0.09$ & 0.52 & 0.05 \\
\hline Sphyrna lewini & 2.7 & $0.017 \pm 0.017$ & $0.01 \pm 0.01$ & 0.014 & 0.002 \\
\hline Carcharhinus dussumieri & 45.94 & $4.84 \pm 2.42$ & $1.66 \pm 0.77$ & 4.2 & 0.3 \\
\hline Rhinobatos annandalei & 2.7 & $0.008 \pm 0.008$ & $0.007 \pm 0.007$ & 0.01 & 0.002 \\
\hline Aetomylaeus nichofii & 8.1 & $0.03 \pm 0.02$ & $0.02 \pm 0.01$ & 0.048 & 0.006 \\
\hline Penaeus merguiensis & 21.62 & $0.017 \pm 0.009$ & $0.52 \pm 0.26$ & 0.02 & 0.13 \\
\hline Sepia pharaonis & 54.05 & $0.2 \pm 0.04$ & $1.1 \pm 0.25$ & 0.2 & 0.22 \\
\hline Charybdis feriata & 5.4 & $0.003 \pm 0.002$ & $0.013 \pm 0.009$ & 0.005 & 0.004 \\
\hline
\end{tabular}




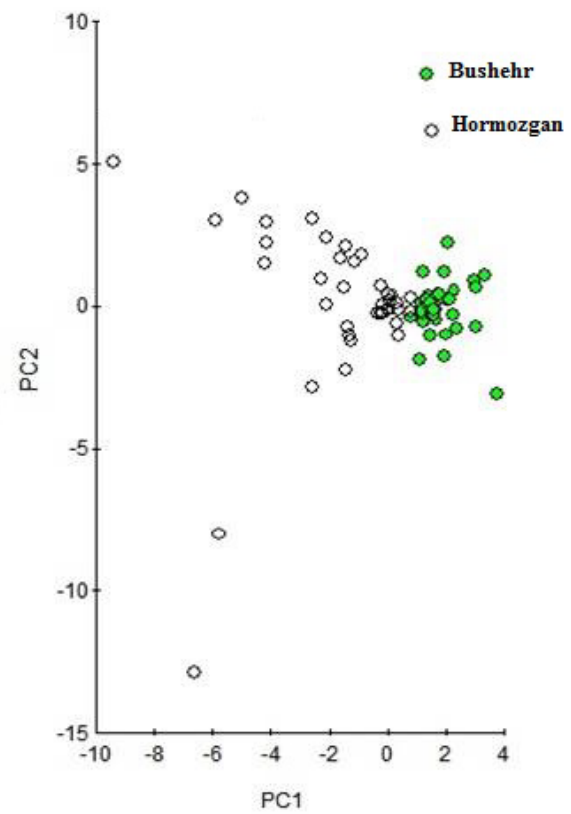

Figure 4. Comparison of bycatch composition based on the weight by Principal Components Analysis (PCA) in Bushehr and Hormozgan provinces, Iran
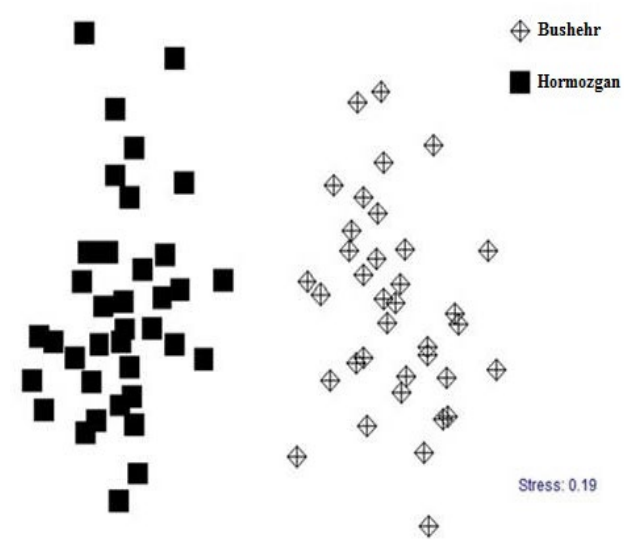

Figure 5. Comparison of bycatch composition based on the weight by Multidimensional Scaling (nMDS) in Bushehr and Hormozgan provinces, Iran

\section{Comparison of catch composition based on the weight}

The results obtained by comparing the catch composition of the fishing operations based on weight by PCA and nMDS methods were indicative of two different communities in cutlassfish fishing zones in Hormozgan and Bushehr provinces. The stress level of 0.19 in nMDS analysis indicates that the results are correct. Also, ANOSIM similarity analysis confirmed the results of PCA and nMDS and showed a significant difference in the composition of the two studied fishing communities ( $\mathrm{P}=$ $1 \%, \mathrm{R}=0.849$ ) (Figure 4; Figure 5).

SIMPER analysis indicated that there is $68.64 \%$ of the weight dissimilarity in the catch composition in Bushehr and Hormozgan. More than $31 \%$ of this dissimilarity was related to 10 species including Polynnemus sextarius (5.2\%), Muraenesox cinereus (3.83\%), Pennahia

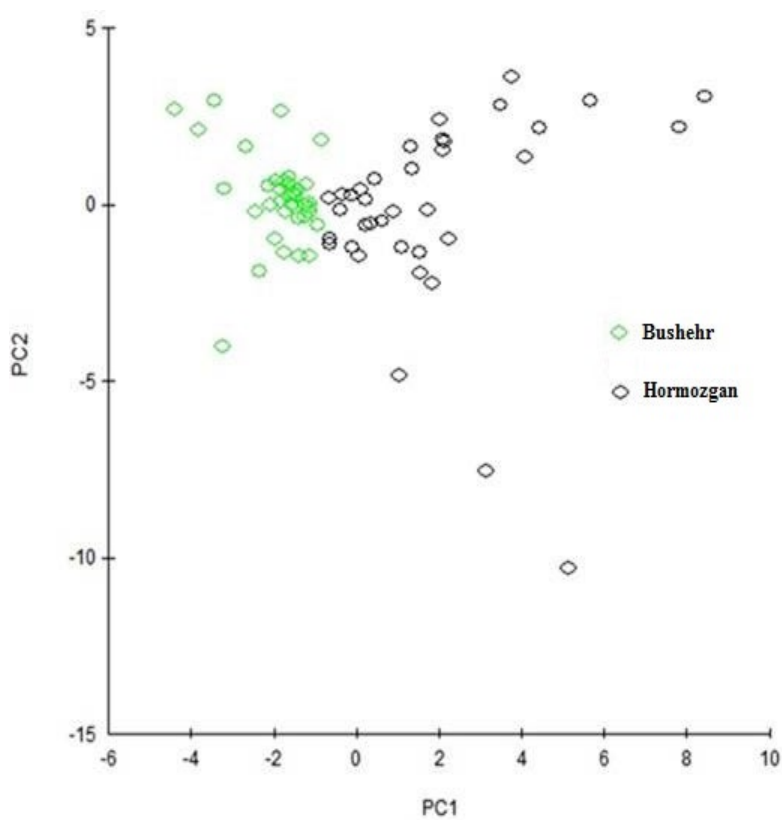

Figure 6. Comparison of catch composition based on the number by Principal Components Analysis (PCA) in Bushehr and Hormozgan provinces, Iran

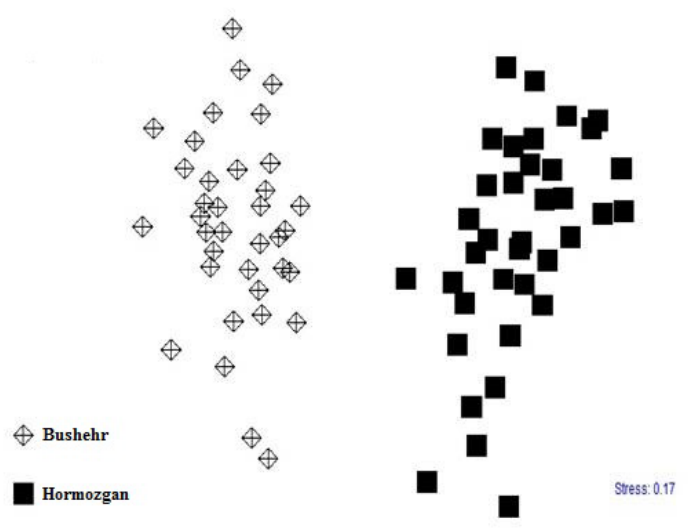

Figure 7. Comparison of bycatch composition based on the number by Multidimensional Scaling (nMDS) in Bushehr and Hormozgan provinces, Iran

macrophthalmus (3.03\%), Himantura walga (2.68\%), Leiognathus equulus (2.67\%), Carangoides malabaricus (2.54\%), Sphyreana putnamiae (2.21\%), Pomadasys kaakan (2.15\%), Nemipterus japonicus (2.11\%), and Carancs sexfasciatus (2.11\%). 5 species including Illisha megaloptera, Saurida tumbil, Nemipterus japonicas, Dussamieria acuta, and Carancs sexfasciatus had the highest weight amounts in Bushehr and 5 species including Polynnemus sextarius, Illisha megalopteran, Pennahia macrophthalmus, Saurida tumbi, and Nemipterus japonicus had the highest weight amounts in Hormozgan.

Comparison of catch composition based on the number

The results obtained by comparing the catch composition of the fishing operations based on the number by PCA and nMDS methods were indicative of two 
different communities in cutlassfish hunting places. The stress level of 0.17 in nMDS analysis indicates that the results are correct. Also, ANOSIM similarity analysis confirmed the results of PCA and nMDS and showed a significant difference in the composition of the two studied fishing communities ( $\mathrm{P}=1 \%, \mathrm{R}=0.866)$ (Figure 6; Figure 7).

SIMPER analysis indicated that there is $67.68 \%$ of the numerical dissimilarity in the bycatch composition of Bushehr and Hormozgan. More than 38\% of this dissimilarity was related to 12 species including Polynnemus sextarius (6.47\%), Leiognathus equulus (4.91\%), Pennahia macrophthalmus (3.95\%), Illisha megaloptera (3.87\%), Carangoides malabaricus (2.82\%), Nemipterus japonicus (2.57\%), Muraenesox cinereus (2.53\%), Selaroides leptolepis (2.28\%), Upeneus salphureus $(2.24 \%)$, Sepia pharaonis (2.15\%), Himantura walga (2.14\%), and Sphyreana putnamiae (2.06\%). Five species including Illisha megaloptera, Dussamieria acuta, Leiognathus equulus, Nemipterus japonicus, and Saurida tumbil had the highest numerical amounts in Bushehr and 6 species including Illisha megalopteran, Polynnemus sextarius, Pennahia macrophthalmus, Nemipterus japonicus, Saurida tumbi, and Carangoides malabaricus had the highest numerical amounts in Hormozgan.

In the study by Hosseini et al (2012) $65 \%$ of the bycatch assemblages biomass between two fishing areas was belonged to $N$. japonicus $(30.5 \%)$, I. melastoma (12.5\%), S. tumbil (8.5\%), A. spinifer (6\%), D. bennetti (4.5\%) and A. thalassinus (4\%). Valinasab et al (2006) have reported spatial variation in biomass for these species in the Persian Gulf. Several studies have also reported temporal variations in bycatch assemblages in tropical regions (Blaber et al. 1990; Gallaway and Cole 1999, Tonks et al. 2007; Paighambari and Daliri 2012; Eighani and Paighambari 2013). These species exist in estuarine and inshore waters. Therefore, considering the effect of coastal abiotic factors on these species might be helpful to realize recruitment processes in offshore zones and describe the observed temporal variations in bycatch community (Carpenter 1997). The variations in cutlassfish bycatch compositions between two fishing zones can be affected by biophysical factors such as salinity, temperature and seasonal movement of water masses and biotic factors such as phytoplankton blooms. The environmental parameters such as salinity, oxygen, and temperature are different in the northwest of the Persian Gulf and close to the Strait of Hormuz with the center and northeast of the Persian Gulf (Kampf and Sadrinasab 2006).

Most of the species in the bycatch combination are commercially valuable aquatic animals. Also, due to the type of net design, these species are exploited before maturation, and other discard species similarly will be destroyed (Valinasab et al. 2006). These species may be economically worthless but play an important role in the marine life cycle. The maintenance of these worthless stocks can prevent excessive exploitation and guarantee the sustainable harvesting of important and high-value commercial stocks (Morgan et al. 2002; Valinasab et al. 2005). Recent fisheries rules aim to control fishing efforts, nevertheless numerous species are presently overfished and fishing effort surpasses that required to extract Maximum Sustainable Yield (MSY) for most demersal species in the Persian Gulf (El Sayed 1996; Dadzie et al. 2005; Grandcourt et al. 2010; Grandcourt 2012). Therefore, further studies in these areas and the implementation of changes to the equipment, fishing effort, harvesting rules, in order to reduce excessive exploitation and pressure on the bycatch species of cutlassfish trawlers is crucial.

\section{ACKNOWLEDGMENTS}

The authors are thankful to the Vice Presidency for Research and Technology of Gorgan University of Agricultural Sciences and Natural Resources (GAU) for their financial support and technical collaborations during the study period.

\section{REFERENCES}

Alverson DL, Freeber MH, Murawski SA, Pope JG. 1994. A Global Assessment of Fisheries Bycatch and Discard. FAO Fisheries Technical. Food and Agricultural Organisation, Rome

Andrew NL, Jones T, Terry C, Pratt R. 1995. Bycatch of an Australian stow net fishery for school prawns (Metapenaeus macleayi). Fish Res 22: 121-136.

Bellido JM, Begona santos M, Grazia Pennino M, Valeiras X, Pierse GJ. 2011. Fishery discards and bycatch: solutions for an ecosystem approach to fisheries management. Hydrobiologia 670: 317-333.

Blaber JM, Brewer DT, Salini JP, Kerr J. 1990. Biomasses, catch rates and abundances of demersal fishes, particularly predators of prawns, in a tropical bay in the Gulf of Carpentaria. Mar Biol 107 (2): 397408.

Carpenter KE. 1997. Living Marine Resources of Kuwait, Eastern Saudi Arabia, Bahrain, Qatar, and the United Arab Emirates. Food and Agricultural Organisation, Rome.

Charles RC, Philip S, Ann MJ, Thereza MB. 2011. Effectiveness of bycatch-reduction devices in roller-frame trawls used in the Florida shrimp fishery. Fish Res 108: 248-257.

Clarke KR. 1993. Non-parametric multivariate analyses of changes in community structure. Aust J Ecol 18 (1): 117-143.

Clucas I. 1997. A study of the option for utilization of bycatch and discards from marine capture fisheries. FAO Fisheries Circular. Food and Agricultural Organisation, Rome.

Dadzie S, Manyala JO, Abou-Seedo F. 2005. Aspects of the population dynamics of Liza klunzingeri in the Kuwait Bay. Cybium 29 (1): 1320.

Davies RWD, Cripps SJ, Nickson A, Porter G. 2009. Defining and estimating global marine fisheries bycatch. Mar Policy 33: 661-672.

Eayrs S. 2007. A Guide to Bycatch Reduction in Tropical Shrimp-Trawl Fisheries. Food and Agricultural Organisation, Rome.

Eighani M, Paighambari SY. 2013. Shrimp, Bycatch and Discard Composition of Fish Caught by Small-scale Shrimp Trawlers in the Hormuzgan Coast of Iran in the Persian Gulf. Philipp Agr Sci 96 (3): 314-319.

El Sayed AFM. 1996. Effects of overfishing and abandoning bottom trawling on Qatar's fisheries. Qatar Univ Sci J 16 (1): 173-178.

FAO. 2007. Fishery statistics. Capture production. Food and Agriculture Organization of the United Nations. 100: 342-350.

Fischer W, Bianchi G. 1984. FAO species identification sheets for fishery purposes. Western Indian Ocean (Fishing Area 51), vols 1-5. Food and Agricultural Organisation, Rome.

Gallaway BJ, Cole JG. 1999. Reduction of juvenile red snapper bycatch in the U.S. Gulf of Mexico Trawl Fishery. N Am J Fish Manage 19 (1): 342-355.

Grandcourt E, Al Abdessalaam TZ, Francis F, Al Shamsi A. 2010. Agebased life history parameters and status assessments of by-catch species (Lethrinus borbonicus, Lethrinus microdon, Pomacanthus 
maculosus, and Scolopsis taeniatus) in the southern Arabian Gulf. J Appl Ichthyol 26 (3): 381-389.

Grandcourt E. 2012. Reef fish and fisheries in the Gulf. In: Riegl B, Purkis S. (eds.), Coral Reefs of the Gulf: Adaptation to Climatic Extremes. Springer Science Business Media, New York.

Harrington JM, Myers RA, Rosenberg AA. 2006. Wasted fishery resources: discarded by-catch in the USA. Fish Fish 6: 350-361.

Hosseini SA, Raeisi H, Paighambari SY. 2012. Temporal and Spatial Variations of Finfish Bycatch of Cutlassfish Trawl in Bushehr and Hormozgan Marine Waters, the Northern Persian Gulf. J Persian Gulf 3 (9): 1-8.

Kampf J, Sadrinasab M. 2006. The circulation of the Persian Gulf: a numerical study. Ocean Sci 2: 27-41.

Kardovani P. 1995. Iranian Marine Ecosystem (The Persian Gulf and the Caspian Sea). Ghomes, Tehran Iran.

Kaymaram F. 2000. Dynamics and management of Thunnus albacarus in the Gulf of Oman. [Dissertation]. Islamic Azad University, Research Center, Tehran.

Kennelly SJ. 1995. The issue of bycatch in Australia's demersal trawls fisheries. Rev Fish Biol Fisher 5: 213-234.

Khan NY, Munawar M. 2002. Physical and human geography. In: Khan NY, Munawar M, Price AR. (eds.), The Gulf Ecosystem, Heath and Sustainability. Backhuys, Nederland.

Kumar BA, Deepthi GR. 2006. Trawling and by-catch: implications on marine ecosystems. Cur Sci 90: 22-31.

Morgan A, Carlson J, Ford T, Siceloff L, Hale L. 2002. Temporal and spatial distribution of finfish bycatch in the U.S. Atlantic bottom longline shark fishery. Mar Fish Rev 2 (1): 34-38.

Paighambari SY, Daliri M. 2012.The bycatch composition of shrimp trawl fisheries in Bushehr coastal waters, northern Persian Gulf. J Persian Gulf 3 (7): 27-36.

Paighambari SY, Eighani M. 2016. Size selection of three commercial fish using sorting grids in the Persian Gulf shrimp trawl fishery. Reg Stud Mar Sci 3: 251-253.

Pauly D, Christensen V, Pitcher TJ, Walters CJ. 2002. Towards sustainability in world fisheries. Nature 418: 689-695.

Pikitch EK, Santora C, Babcock EA, Bakun A, Bonfil R, Conover DO, Dayton P, Doukakis P, Fluharty D, Heneman B, Houde ED, Link J, Livingston PA, Mangel M, McAllister MK, Pope J, Sainsbury KJ. 2004. Ecosystem-based fishery management. Science 305 (5682): 346-347.

Price ARG. 1993. The Gulf: Human impacts and management initiatives. Mar Pollut Bull 27: 17-27.
Queirolo D, Erzini K, Hurtado CF, Gaete E, Soriguer MC. 2011. Species composition and bycatches of a new crustacean trawl in Chile. Fish Res 110: 149-159.

Raeisi H, Hosseini SA, Paighambari SY, Taghavi SAA, Davoodi R. 2011. Species composition and depth variation of cutlassfish (Trichiurus lepturus L. 1785) trawl bycatch in the fishing grounds of Bushehr waters, Persian Gulf. Afr J Biotechnol 10 (76): 17610-17619.

Raeisi H, Hosseini SA, Paighambari SY, Shabani MJ, Kiaalvandi S. 2012. Study of Natural and Fishing Mortality and Exploitation Rate of Largehead hairtail, Trichiurus lepturus (Linnaeus, 1758) from the Northern Persian Gulf, Iranian waters. Caspian J Appl Sci Res1 (7): 22-26.

Rochet MJ, Isabelle P, Verena M. 2002. An analysis of discards from the French trawler fleet in the Celtic Sea. ICES J Mar Sci 59 (3): 538552.

Sale PF, Feary DA, Burt JA, Bauman AG, Cavalcante GH, Drouillard KG, Kjerfve B, Marquis E, Trick CG, Usseglio P, Van Lavieren H. 2011. The growing need for sustainable ecological management of marine communities of the Persian Gulf. Ambio 40 (1): 4-17.

Sheppard C, Al-Husiani M, Al-Jamali F, Al-Yamani F, Baldwin R, Bishop J, Benzoni F, Dutrieux E, Dulvy NK, Durvasula SRV, Jones DA, Loughland R, Medio D, Nithyanandan M, Pilling GM, Polikarpov I, Price ARG, Purkis S, Riegl B, Saburova M, Namin KS, Taylor O, Wilson S, Zainal K. 2010. The Gulf: A young sea in decline. Mar Pollut Bull 60 (1): 13-38.

Tonks ML, Griffiths SP, Heales DS, Brewer DT, Dell Q. 2007. Species composition and temporal variation of prawn trawl bycatch in the Joseph Bonaparte Gulf, northwestern Australia. Fish Res 89 (3): 276293.

Valinassab T, Daryanabard R, Dehghani R, Pierce GJ. 2006. The abundance of demersal fish resources in the Persian Gulf and Oman Sea. J Mar Biol Assoc UK 86 (1) 1455-1462.

Valinassab T, Dehghani RE, Khorshidian K. 2005. Biomass estimation of demersal resources in the Persian Gulf and the Gulf of Oman by swept area method. Final Report. Iranian Fisheries Research Organization (IFRO), Tehran.

Walmsley SA, Leslie RW, Sauer WHH. 2007. Bycatch and discarding in the South African demersal trawl fishery. Fish Res 86 (2): 15-30.

Worm B, Barbier EB, Beaumont N, Duffy JE, Folke C, Halpern BS. 2006. Impacts of biodiversity loss on ocean ecosystem services. Science 314: 787-790. 